University of Nebraska - Lincoln

DigitalCommons@University of Nebraska - Lincoln

Spanish Language and Literature

Modern Languages and Literatures, Department

2009

From the Self to the Nation: Willpower in José María Salaverría

Iker González-Allende

University of Nebraska-Lincoln, igonzalezallende2@unl.edu

Follow this and additional works at: https://digitalcommons.unl.edu/modlangspanish

Part of the Modern Languages Commons

González-Allende, Iker, "From the Self to the Nation: Willpower in José María Salaverría" (2009). Spanish Language and Literature. 39.

https://digitalcommons.unl.edu/modlangspanish/39

This Article is brought to you for free and open access by the Modern Languages and Literatures, Department of at DigitalCommons@University of Nebraska - Lincoln. It has been accepted for inclusion in Spanish Language and Literature by an authorized administrator of DigitalCommons@University of Nebraska - Lincoln. 


\title{
FROM THE SELF TO THE NATION: WILLPOWER IN JOSÉ MARÍA SALAVERRÍA
}

\author{
IKER GONZÁLEZ-ALLENDE
}

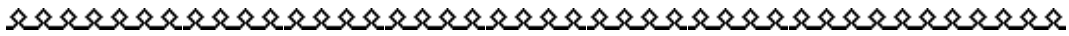

José María Salaverría's (1873-1940) inclusion into Spain's so-called Generation of 1898 seems questionable for many critics. In classical studies about the writers of this generation, such as those by José Luis Abellán, Donald Shaw or Inman Fox, Salaverría is not present. Even in more recent works, for instance Nuevas perspectivas sobre el 98 (1999), edited by John Gabriele, or Spain's 1898 Crisis (2000), edited by Joseph Harrison, no chapter investigates Salaverría's contributions to Spanish literature in this period. Salaverría shares many characteristics with the members of the Generation of 1898: He was born in the same era, grew up in Spain's periphery, praised the region of Castille, and mostly cultivated the essay genre. Nevertheless, he showed some deviations from the authors of the Generation of ' 98 : He did not receive a university education, started to publish later - in 1906 -, traveled around the world, and maintained a very critical attitude towards his contemporary writers. Thus, in Retratos (1926) and Nuevos retratos (1930), Salaverría disparages authors such as Pío Baroja, Miguel de Unamuno, Ramiro de Maeztu and Azorín.

Although biographical approaches to study literature may be problematic, Salaverría's personal circumstances and auto-marginalized position among his writing contemporaries seem essential to understanding his own theories about Spain. The difficulties that Salaverría had to face in his private life because of his shy manner and humble social class made him believe in the necessity of self-improvement and willpower. His vision for Spain tends to follow a similar path. The solution he finds to solve the crisis the country was experiencing at the beginning of the twentieth century involves awakening its citizens and creating a transna- 
tional spiritual homeland consisting of Spain and Spanish America. Therefore, Salaverría considers willpower to be necessary in both the personal and the national realms. In his book La afirmación española (1917), he expresses these thoughts clearly: "Lo que yo deseo es llevar mi pasión hasta la idea de España y fundirme místicamente con España, de manera que, para afirmarme a mí mismo y escapar al aniquilamiento de mi ser, necesite afirmar a mi Patria, justificarla, exaltarla" (134). ${ }^{1}$

The concept of willpower is derived from Arthur Schopenhauer, who is usually considered the philosopher who exerted the greatest influence on the Generation of 1898 (Abellán 29). According to Schopenhauer, the principle that governs the universe is the will to live, and all energies in nature are an expression of this will. The same happens with human beings, for whom life is a task to be performed; due to their consciousness, though, the will becomes a continuous wish that is never totally satisfied. Hence, Schopenhauer believes that human life is suffering, and when the pain can be avoided, the only feeling that remains is boredom (232). The presence of this pessimism appears in the abulia or apathy from which many literary characters in the novels of the Generation of ' 98 suffer. However, Schopenhauer's ideas were not assimilated integrally in Spain, since most Spanish intellectuals softened his pessimistic doctrine (Alonso 32).

In several works of the writers of ' 98 , the will to live was transformed into will to power, following Friedrich Nietzsche's premises. Gonzalo Sobejano has extensively documented Nietzsche's influence on these authors, especially through the concepts of the superman ("Übermensch"), eternal return, atheism, importance of life, opposition to democracy, bureaucracy and socialism, and prominence of aristocratic individualism (480-85). ${ }^{2}$ Salaverría followed many of these principles, as some of his contemporaries documented. ${ }^{3}$ Salaverría himself offers

${ }^{1}$ La afirmación española is possibly Salaverría's most Nietzschean work. Apart from criticizing the pessimism of the Generation of ' 98 , in this book, he defends the conquest of America and advocates the need for national optimism.

${ }^{2}$ Sobejano points out that in a 1918 article in the newspaper $A B C$, Salaverría indicated that Spain's modern writers were Nietzschean and that no thinker in the previous thirty years had influenced Spanish intelligentsia as much as he had (134). In fact, several authors of the Generation of ' 98 , such as Azorín, Baroja and Maeztu, frequently utilized Nietzschean ideas in their works.

${ }^{3}$ Pío Baroja, for instance, indicates in his memoirs that Salaverría showed Nietzsche's influence when this was already outdated in Spain after Maeztu's publications 
the key to understanding Nietzsche's influence on him when he writes that Nietzsche's followers were the weak and the decadent, since "quien es sano y fuerte de suyo no necesita el estimulante nietzscheano" (Sobejano 134). In some of the letters Salaverría sent to Unamuno, he insists on his shyness and lack of social skills: "No sé hablar ni exhibirme, no sé murmurar, no digo gracias, soy tardo en comunicarme y tengo el trato social muy solemne y en la amistad al estilo corriente creo que soy insípido" (Tellechea 28). Consequently, he would have followed Nietzsche's thoughts to counteract his personal flaws and inabilities, as well as the decadence of the nation.

The fact that Salaverría was born to a lower-class family - his father worked as a lighthouse keeper, while his mother was a peasant - made his success in literary and cultural life very difficult. He randomly read the books he could find, about which he complained later, calling himself "un trapero de la cultura" (Bilbao Notario 189). Despite these difficulties, his highest aspiration was to write in Madrilean newspapers, which he achieved in 1906. However, Salaverría used to complain about the capital's literary scene, claiming that in order to excel, writers needed an attractive and extroverted personality, as well as physical distinction, something he lacked. For this reason, when describing the members of the Generation of '98, Salaverría criticizes what he calls their "pose": Valle Inclán's long beard and hair, Unamuno's vest and bow tie, Azorín's monocle and red umbrella, and Maeztu's "furia epiléptica" (Nuevos retratos 64). This proves how in early twentieth-century Spain, like in today's literary market, the way writers present themselves in public has significant consequences on the sale of their books.

Another aspect with which Salaverría struggled as an author was the importance of friendships and connections, for instance, in order to receive positive reviews of his books. From his perspective, in literary circles, the social contacts of authors were as vital as the quality of their works. In his own words, "El escritor que no pertenece a cualquier grupo de amigos está indefenso y ha de pagar duramente el lujo de su orgullo o de su originalidad de carácter" (Retratos 22). Salaverría protested this situation because he believed that his lack of writer

(Sobejano 446). Miguel de Unamuno also noticed the presence of Nietzsche's ideas in Salaverría's first novel, El perro negro (1906), and in a letter advised him to abandon them (Tellechea 55). 
friends caused Spanish readers to be ignorant of his books, and therefore, he could not influence them or reach posterity.

On the other hand, in Madrid, Salaverría experienced the rampant competitiveness present in publishing houses and newspapers. It is relevant to remember that most of the members of the Generation of ' 98 were from the periphery of Spain, and many of them, such as Salaverría himself, from the Basque Country. These writers came to Madrid to pursue literary careers, which caused them to behave very competitively. Salaverría's description of his ostracism from Spanish literary circles is clearly demonstrated in the last chapter of his book Nuevos retratos, entitled "Salaverría más Salaverría" (219-31). In this chapter, he relates the fictional story of his division into two after drinking an Indian fakir's liquor. His conscious spirit follows his physical other and listens to how some writers criticize him, saying that he does not write well in Spanish and that he adulates the old academics (228). They also mock the fact that he goes to church and that his family belongs to the working class. Here Salaverría is again portraying himself as a marginal writer and victim of the leading literary circles. It seems that he somehow enjoyed depicting this image of himself, since he made an effort to be an isolated writer and to be hated by his contemporaries. However, during certain periods, he befriended some of them, and although he criticized them publicly, he continued reading their works (Navarra 46).

Despite all these difficulties or perhaps because of them, Salaverría did not abandon his aspiration to become a famous author. Salaverría's perseverance in finding a space in the Spanish literary market coincides with some of the ideas that Nietzsche expressed in Thus Spoke Zarathustra (1883-1885). For Nietzsche, man has to be overcome because "he is an overture and a going under" (399). According to him, evil and suffering are necessary so that the superman can grow stronger. Nietzsche also advocated optimism in the presence of failure: "A throw had failed you. But, you dice-throwers, what does it matter? [...] The higher its type, the more rarely a thing succeeds. You higher men here, have you not all failed?" (404). Salaverría expressed similar ideas in a letter to Unamuno: "Seguiré, en efecto, escribiendo libros, porque aunque los fracasos me duelen de veras, aun los esperados, hay un impulso fatal que me obligará toda la vida a obrar" (Tellechea 54). He actually never enjoyed the fame he would have wished, because like many of his contemporaries, he had to write newspaper articles to earn his living and the 
other literary genres he cultivated, such as the biography and the novel, are mostly essayistic and do not involve great creativity.

Salaverría's multiple trips and stays abroad can be considered examples of his dynamism and search for personal redemption. Besides visiting Spanish America on several occasions and living in Argentina from 1910 until 1913, he worked as a correspondent in Europe during World War I. As a result of these experiences, Salaverría wrote several travel books, among which the ones dedicated to Argentina stand out because in them he developed his theory of Hispanidad and applied his concept of individual willpower to the nation.

In his analysis of Spain's situation at the beginning of the twentieth century, Salaverría underlines the decadence in a similar way to the other members of the ' 98 . His objective to regenerate his country is clearly nationalistic and ideological, and in fact, helped to construct the conservative image of Spain prevalent during Franco's dictatorship. As Benedict Anderson points out, nationalism is a cultural artifact that lies in the creation of an imagined community (4-6). The development of the novel and the newspaper since the eighteenth century especially contributed to the spread of the representation and narration of the nation. For this reason, several scholars of nationalism, such as Eric Hobsbawm, have emphasized the modernity of nations, the fact that nationalism comes before nations, and that this ideology is constructed through invented traditions handed down from above, from the intellectuals (10). Similarly, Salaverría created a negative vision of the Spain of his time and mourned for its lost imperial past to convey a clear nationalistic message: to ask his readers to participate actively in the improvement of the country.

In A lo lejos: España vista desde América (1914), Salaverría compares Spain's situation with that of Argentina. The physical distance from his country allowed him to seem objective when describing it. In a similar way as when narrating the difficulties he experienced as a writer and the ostracism he had to bear, here the author focuses on creating the image of a backward and "different" Spain to inspire commiseration and to call for change. For Salaverría, the most clear example of Spain's downfall is that Spanish American countries do not remember Spain anymore (87). As Ángel Loureiro states, at the beginning of the twentieth century, the Spanish discourse on Spanish America was elaborated in terms of loss and ruin and its main objective was to promote Spain's 
self-understanding rather than to investigate the present status of Spanish American countries (65).

Salaverría's accounts of Spanish America also become an opportunity for him to discuss Spain's historical influence on the continent and reminisce about the Spanish Empire in the sixteenth century. He emphasizes the Spanish traces in Argentina; for instance, the architecture, the figure of the gaucho and the Spanish language. He even finds similarities between the Argentinean Pampas and the plateau of Castille, which implies that, from his point of view, even Spanish American nature has its origins in Spain. As Jo Labanyi explains, the Generation of '98's fixation with Castille as representation of a pure and authentic Spain provides an image of a solid and enduring natural foundation on which to build the nation (138). For Salaverría, Spain's imperial past proves that the nation has an innate strength to pursue heroic deeds. In fact, he explains Spain's apathy as a consequence of the country expending all its national energy in the sixteenth and seventeenth centuries.

According to Salaverría, the solution for the nation's decadence lies in the reemergence of willpower. This conception of the nation is similar to the one that Ernest Renan proposed in 1882. For Renan, nations are not defined by objective criteria such as race, religion, geography, language, or common interests, but by the desire of the people to live together. This is precisely what Salaverría intends: to remember the past in order to encourage the creation of a prosperous national future. His task is to awaken the sleeping warlike Spanish conscience. Thus, in Vieja España (1907), he addresses the Cid, the hero of the Catholic Reconquest in the eleventh century, and turns him into the Spanish Zarathustra, into the leader who will inspire new national achievements. Similarly, Nietzsche's superman becomes in Salaverría "a summit man": "[...] la humanidad quiere perfeccionarse y crear nuevos tipos, más fuertes y hermosos que los anteriores; y todo el ondular turbio del río de la muchedumbre se dirige a un solo fin, que es el crear un libro, una idea, un hombre-cúspide como César, como Cristo o como Borgia, bueno o malo, pero siempre más alto" (147). Here, there is a clear connection between the individual and literary aspiration on one hand, and the national ambition on the other.

Apart from his appeal for violence, Salaverría considers an alliance with Spanish America a solution to Spain's national crisis. The optimism and prosperous economy that Salaverría found in Argentina made him 
believe that his country should follow its steps. Thus, he thinks that Spain ought to forget Europe, which he found in crisis when working as a war correspondent. For Salaverría, the ultimate goal for Spain is the creation of a Hispanic civilization where all the citizens speak the Spanish language: "Es la aspiración a una extensa patria lingüística, la patria de los hombres que hablan castellano en dos continentes. Aspiración, en suma, hacia una España más grande... [...]. España se verá arrastrada en la corriente de sus hijas de América, uniéndose a ellas su destino" (A lo lejos 92). Already in 1914, Salaverría was suggesting the idea of Hispanicity, although not explicitly. In 1909, Miguel de Unamuno was the first Spanish intellectual to coin the term Hispanidad to refer to the fraternity between Spain and Spanish America (Zuleta Álvarez 91). However, today Ramiro de Maeztu is the writer more associated with this idea due to his work Defensa de la Hispanidad (1934), which was used frequently by Francoist ideologues. As is known, Maeztu proposes that Hispanidad is the spiritual homeland of all the Hispanic countries based on the Catholic religion and the monarchy.

The Hispanidad that Salaverría suggests is ambiguous. On one hand, he writes that in this transatlantic Hispanic nation Spain will not behave "como una madre que pretende especiales privilegios, sino como simple hermana" (194). However, the constant references in his work to the legacy that Spain left in Spanish America and the fact that he previously called those countries "American daughters" entail the intention of a leadership role for Spain. As Loureiro points out, Latin America is seen by Spaniards at this time as "symbolic and material compensation for Spain's economic and political dejection" (69).

Undoubtedly, Salaverría's life and work were clearly influenced by Nietzsche's thinking. As Sobejano states, he transformed himself into a professor of Nietzschean energy and aristocracy, probably to compensate for his weak and mild character (460). Salaverría's desire for fame and power made him persist in his literary career despite the great amount of difficulties he experienced. Similarly, he believed in solving Spain's decadence with an appeal for strength. Through his books, Salaverría wanted to reinforce his persona and at the same time convey optimism about the nation's future. His ego and the nation became a convergent reality, since Spain's victories would mean a reaffirmation of himself. However, in reality, his willpower was a mechanism to mask his personal failures as a writer and the critical condition that Spain was 
facing. That is, his appeal for will to power did not produce actual positive changes: Salaverría did not achieve literary recognition, and until recently there were very few studies about his works, while Spain's situation did not improve for many years.

\section{UNIVERSITY OF NEBRASKA-LINCOLN}

\section{WorKs Cited}

Abellán, José Luis. Visión de España en la Generación del 98. Madrid: Magisterio Español, 1968.

Alonso, Cecilio. "Notas sobre el pesimismo activo en la literatura española hacia 1900 (Un fin de siglo entre la voluntad y el dolor de vivir)." Anales de Literatura Española 12 (1996): 27-54.

Anderson, Benedict. Imagined Communities: Reflections on the Origin and Spread of Nationalism. London: Verso, 1991.

Bilbao Notario, Miren. "José María Salaverría: vida y pensamiento (1873-1940)." Letras de Deusto 28.80 (1998): 185-204.

Fox, E. Inman. Ideología y política en las letras de fin de siglo (1898). Madrid: Espasa Calpe, 1988.

Gabriele, John P., ed. Nuevas perspectivas sobre el 98. Madrid: Iberoamericana; Frankfurt: Vervuert, 1999.

Harrison, Joseph, and Alan Hoyle, eds. Spain's 1898 Crisis: Regenerationism, Modernism, Postcolonialism. Manchester: Manchester UP, 2000.

Hobsbawm, Eric. Nations and Nationalism Since 1780: Programme, Myth, Reality. Cambridge: Cambridge UP, 1992.

Labanyi, Jo. "Nation, Narration, Naturalization: A Barthesian Critique of the 1898 Generation." New Hispanisms: Literature, Culture, Theory. Ed. Mark I. Millington and Paul Julian Smith. Ottawa: Dovehouse, 1994. 127-49.

Loureiro, Ángel G. "Spanish Nationalism and the Ghost of Empire." Journal of Spanish Cultural Studies 4.1 (2003): 65-76.

Navarra, Andreu. "Un programa político antieuropeísta: La afirmación española de José María Salaverría." Sancho el Sabio 24 (2006): 35-56.

Nietzsche, Friedrich. The Portable Nietzsche. Ed. Walter Kaufman. New York: The Viking, 1954.

Renan, Ernest. "What is a nation?" Nation and Narration. Ed. Homi K. Bhabha. London: Routledge, 1990. 8-22.

Salaverría, José María. La afirmación española: Estudios sobre el pesimismo español y los nuevos tiempos. Barcelona: Gustavo Gili, 1917.

—. A lo lejos: España vista desde América. Madrid: Renacimiento, 1914.

- Nuevos retratos. Madrid: Renacimiento, 1930.

- Retratos. Madrid: Enciclopedia, 1926.

- Vieja España (Impresión de Castilla). Madrid: Librería de los Sucesores de Hernando, 1907. 
Schopenhauer, Arthur. The Will to Live: Selected Writings. New York: Frederick Ungar, 1967.

Shaw, Donald L. La generación del 98. Madrid: Cátedra, 1978.

Sobejano, Gonzalo. Nietzsche en España. Madrid: Gredos, 1967.

Tellechea Idígoras, J. Ignacio, ed. Miguel de Unamuno y José María Salaverría. Epistolario (1904-1935). Donostia-San Sebastián: Kutxa, 1995.

Zuleta Álvarez, Enrique. España en América: Estudios sobre la historia de las ideas en Hispanoamérica. Buenos Aires: Confluencia, 2000. 